\title{
Welfare to Work in Australia: disability income support, housing affordability and employment incentives
}

\author{
by
}

Tony Dalton, AHURI/NATSEM Research Centre, RMIT

Rachel Ong, AHURI Research Centre, Murdoch University

\author{
Address for correspondence: \\ Professor Tony Dalton \\ AHURI/NATSEM Research Centre \\ RMIT University \\ GPO Box 2476V \\ Melbourne Victoria 3001 \\ Email: Tony.Dalton@rmit.edu.au
}


Abstract: Internationally considerable policy attention is being paid to increasing the employment participation of disabled working age people. Like other OECD countries, Australia has experienced growth in the number of Disability Support Pension (DSP) recipients due to changes in industry structure and increases in precarious employment. This history is well-rehearsed in policy debates. However, little research attention has been given to the housing circumstances of DSP recipients. This is important, particularly when we note the increasing incidence of working age DSP recipients in the private rental market and public housing. For public renters the incidence has more than tripled to $27 \%$ over the period $1982-2002$. This paper addresses two questions 'What are the housing circumstances of DSP recipients?' and 'What are the likely consequences of program changes aimed at increasing employment participation of DSP recipients?' Using Australia as an example this article considers interactions between the new disability payment system being implemented through Welfare to Work, housing costs and employment income. 


\section{Introduction}

In Australia the primary social security payment for disabled working age persons is Disability Support Pension (DSP) ${ }^{1}$. DSP receipt is traditionally associated with low labour force participation levels. It is a non-activity-tested payment, so a disabled person is not obligated to engage in job-seeking activities to receive DSP. In 2002 approximately 88\% of DSP recipients were economically inactive ${ }^{2}$ and only one-tenth of DSP recipients were employed. In contrast, in the same year only one-fifth of working age persons not receiving DSP were economically inactive. Those not in receipt of DSP were seven times as likely to be employed as DSP recipients ${ }^{3}$.

In recent years disability policy in OECD countries has moved away from guaranteeing income security and emphasizing the importance of economic participation. Australia, along with countries like United Kingdom, Sweden, Denmark and Germany, have reduced disability cash benefit levels while increasing efforts to assist disabled people to gain employment (Mont 2004). In Australia the focus on DSP recipients is also being considered more broadly in the context of growth in the number of 'economically inactive' adults, particularly men (Lattimore 2007). This is the context for the May 2005 Australian Government announced in the Budget 2005-2006 new Welfare to Work arrangements that 'people with disabilities applying for welfare who can work part-time will be required to seek part-time work’ (Australian Government 2005). In November 2005 this requirement was enacted in the Employment and Workplace Relations Legislation Amendment (Welfare to Work and Other Measures) Act 2005 (Parliament of Australia 2005). New disabled applicants assessed as being able to work at least 15 hours 
per week would no longer be eligible for the non-activity-tested DSP. Instead like other unwaged working age persons, they would be eligible for a less generous activity-tested unemployment benefit called Newstart Allowance (NSA), payable only to persons seeking work.

Following the budget announcement there has been considerable public debate about the likely outcomes of this proposed change. The Australian Council of Social Service (ACOSS), the main peak organisation for non-government welfare service providers, argues that the chief effect will be to divert approximately $80 \%$ of new DSP applicants from the higher DSP payment to the lower NSA payment. It estimates that these applicants, if they remain on NSA, because they cannot find employment, will receive $\$ 40$ per week less ${ }^{4}$ (Australian Council of Social Service 2005). The Australian Government on the other hand argues that a combination of the new 15-hour work test and Job Network services will result in a significant proportion of DSP applicants finding employment (House of Representatives Standing Committee on Employment Workplace Relations and Workforce Participation 2005).

The parameters of this debate for and against changes to the DSP work test are well developed. However, there is a significant lacuna in this debate. There has been no examination of the housing circumstances of current DSP recipients, nor any attempt to forecast the housing circumstances of future applicants. A reading of recent reports confirms this lacuna. The report Job Network Disability Support Pension Pilot (Evaluation and Programme Performance Branch Employment Analysis and Evaluation 
Group 2004) indicates no consideration was given to the housing circumstances of DSP recipients participating in a pilot program run through twelve Job Network providers aimed at increasing labour market participation. The annual report Characteristics of Disability Support Pension Customers (Office of Disability 2004) goes only so far as to note the housing tenure composition of DSP recipients in terms of 'home owners' and 'non-home owners'. Also the national parliament has not considered the housing circumstances of future DSP applicants. Both the reports of the Standing Committee on Employment Workplace Relations and Workforce Participation (2005) and Community Affairs Legislation Committee (2005) make only passing reference to housing costs. In sum, there is no considered discussion of housing in the lives of DSP recipients and future applicants.

There is a prima facie case that the housing circumstances of DSP recipients do matter because of the connection between disability, poverty and housing stress. Saunders (2005) finds that 'having a household member with a disability is associated with a substantial increase in the incidence of financial hardship, a higher probability of experiencing severe financial stress'. In 2002, the average disposable income of DSP recipients was only half the average disposable income of working age persons not receiving DSP. In the 2002 Household, Income and Labour Dynamics Australia (HILDA) Survey, $12 \%$ of DSP recipients stated that they could not pay their mortgage or rent on time, compared to $8 \%$ of working age persons not receiving DSP. 
The extent to which DSP recipients can be lifted out of financial and housing stress is potentially linked to their propensity to increase income through employment. Hence, affordable housing is most needed in locations with employment opportunities and essential services. However, in Australia the amount of well-located, affordable housing available to low-income persons, such as the disabled, is declining dramatically (Yates $2005)^{5}$. Moreover, the degree to which work disincentives are built into the structure of the DSP program will influence the likelihood of seeking employment. DSP recipients may face an unemployment trap, whereby the simultaneous increase in tax liabilities and withdrawal of government benefits and housing assistance create a high work disincentive that trap low-income persons in cycles of poverty and non-employment. Mont (2004) notes that persons who go on disability programs rarely exit into employment with the outflow rate of only about $1 \%$ in Australia and other OECD countries such as the United States and Canada.

This is the context for two questions addressed in this paper: 'What are the housing circumstances of DSP recipients?' and 'What are the likely consequences of announced program changes aimed at increasing employment participation of DSP applicants diverted onto NSA?' The paper responds to these questions in six parts. First, the paper describes the growth in DSP recipients and reviews the research analysing this growth. It is important that the broader trends and underlying causes are recognised before considering the DSP-housing relationship. Second, the paper presents an analysis of the housing circumstances of DSP recipients by describing the distribution of DSP recipients in the homeownership, private rental and public rental tenures. This highlights the 
increasing incidence of DSP receipt in the private rental and public rental tenures. Third, the institutional context is described by outlining the tax-benefit and housing assistance programs in Australia. This is followed by an account of the DSP and NSA regimes and the methodology that has been used to simulate outcomes for the NSA regime that can be compared with the DSP regime. Fourth, the impact on housing affordability under the NSA regime is presented. Fifth, the impact on work disincentives for each of the tenure groups is presented. Finally, the paper illustrates the impact of the changes on real-life cases by presenting simulation results for two case studies.

\section{Growth in DSP}

The number of DSP recipients has been growing steadily for more than three decades as indicated in Figure 1. During this period there have been three distinct stages, 1972-1980, 1983-1991 and 1992-2004 and in each the rate of increase in DSP recipients has grown. Only in the period 1980-1983 did the number of DSP recipients decline. Overall, the increase in DSP recipients in the period 1972-2004 has been approximately 400\%.

Figure 1 here

Behind this increase in numbers there has also been an increase in expenditure through the DSP program. In 1995 constant Australian dollars there has been a 160\% increase in the period 1980-2000 and GDP terms has increased from 0.6 to 1\% of GDP (OECD 2003). OECD data show that similar to Australia there has been growth in disability support payments in other OECD countries (OECD 2003:17). In the period 1990-1999 the average for twenty OECD countries increased by 0.08 percentage points, from 1.22 to 
$1.30 \%$ of GDP. In this period only six countries experienced a decline in the percent of GDP expended on disability benefits while the other fourteen, including Australia, experienced an increase. This comparative data shows that it had the fifth highest increase, from 0.51 to $0.86 \%$ of GDP in the $1990-1999$ period.

The increase in DSP recipients has been well researched and summary conclusions can be drawn from this research about the characteristics and causes of growth. There is considerable evidence that structural change in Australian industry has been a major cause of the increase. Argyrous \& Neale (2001) confirm the earlier Cass et al (1988) analysis by arguing that the rate of increase began in the 1970s as older males faced a weakening labour market due to a loss in 'traditional' male full-time jobs, especially in manufacturing. They argue that causality stems primarily from labour market change and introduce the term 'labour market disabled'. Cai \& Gregory (2004) similarly find that 'worsening labour market conditions, represented by an increase in the unemployment rate, led to an increase in the number of DSP recipients'. At the same time disability policy and practices are framed within the income security system and used to define the criteria for assessing applicants and how these criteria should be applied (Galvin 2003; 2004; Cai \& Gregory 2002; 2004). For example, Cai \& Gregory (2002; 2004) point in particular to the 1991 policy change when eligibility criteria were relaxed and resulted in an increase in recipients.

DSP recipients have an age, gender and type of disability profile. First, older people are more likely to become DSP recipients. For new recipients in the period 1995-2000 70\% 
of women and $70 \%$ of men were aged 40 or more. Further, among those aged 40 or more the men were more likely to be older (Chalmers \& Siminski 2003 40). Another analysis of the age-disability connection argues that 'disability onset is more likely the older a person gets, and the employment consequences of disability appear to be worse the older the age of onset' (Wilkins 2004). Second, the proportion of women entrants has increased (1995-2000 33\%-43\%) and the proportion of men (1995-2000 67\%-57\%) has decreased. However, this has more to do with changes to the income security system than change in the labour market or rate of disability amongst women (Chalmers \& Siminski 2003). Third, the three largest groups of DSP recipients are those with a musculoskeletal/connective tissue condition (34\%), a psychological/ psychiatric illness (25.4\%) and an intellectual/learning medical condition (10.7\%) (Office of Disability 2004). Considered against the background of age the musculoskeletal connective tissue condition increases significantly with age. On the other hand the psychological/ psychiatric illness and intellectual/learning medical condition decreases with age (Chalmers \& Siminski 2003).

Evidence of the time spent on DSP can only be calculated in terms of 'duration of completed spells' on DSP. The analysis shows that the average duration of completed spells on DSP was 9-10 years. This duration varied a little depending on whether recipients were transferring from another form of income support, in which case their average completed duration spell was longer, or those who came from outside the income support system, in which case they had a shorter average completed duration (Cai 2002). 
There is also a spatial variation in the distribution of DSP recipients that reinforces the argument that DSP incidence is associated with labour market change. Older industrial provincial centres, such as Wollongong and Newcastle and capital cities with lower rates of economic growth such as Adelaide and Hobart, exhibit higher DSP recipient rates (Healy 2002). Within metropolitan Melbourne Berry et al (2005) suggest a similar association between areas that have experienced industrial restructuring and higher DSP recipient rates. DSP recipients are also a group in internal migration patterns and indicate a flow from major cities and the dry inland areas to smaller communities, especially to temperate costal areas (Morrow 2000). This often involves change in housing tenure, including leaving public housing, changing from owner to renter and paying increased rent (ibid).

\section{DSP recipients and their housing}

The housing circumstances of DSP recipients can be understood initially by examining their tenure. Using the Australian Survey of Income and Housing Costs (SIHC), the percentage of DSP recipients among working age persons, in each housing tenure, for the period 1982-2002, is presented in Figure 2. Outright owners are homeowners with no mortgage. Owner purchasers are homeowners financing their home purchase with a mortgage. Private renters rent from landlords apart from a state housing authority (SHA). Public renters rent from a SHA. Those living rent-free neither own nor rent and are

excluded from the analysis. Several noteworthy trends can be observed from Figure 2 about how the growing number of DSP recipients has intersected with housing tenure arrangements in the last two decades. 


\section{Figure 2 here}

As shown in Figure 2, between 1982 and 2002 the percentage of DSP recipients slightly more than doubled among outright owners, owner purchasers and private renters. This increase was from $3 \%$ to $7 \%$ among outright owners, $0.7 \%$ to $1.8 \%$ among owner purchasers and $2 \%$ to $4.5 \%$ among private renters. Notably, the DSP rate more than tripled among public renters from $8 \%$ to $27 \%$.

Among outright owners this increase is overwhelmingly amongst older persons. In 2002, $21 \%$ of DSP recipients in outright ownership were in the $45-54$ band and $69 \%$ in the 55 64 age band. Like outright owners, purchasers and public renters receiving DSP were concentrated into the $45-54$ and 55-64 bands (38\% in each band) though they tended to be younger than outright owners. The age profile of private renters receiving DSP differed with a more even distribution of persons at approximately 25\% across the $25-34$, 35-44, 45-54 and 55-64 age bands.

In 2002, outright owners made up 36\% of DSP recipients, followed by private renters (30\%), public renters (19\%) and purchasers (15\%). This provides evidence of what Castles (1997:108) argues is the 'home ownership effect' on retirement decisions, where 'the possession of a home free of mortgage lowers the income threshold at which an individual can contemplate exit from the labour market’. However, the tenure most overrepresented among the DSP population is public housing. Whereas public renters were only $3 \%$ of the working age population in 2002, the percentage of public renters among 
the DSP population was six times as high at $19 \%$. The sharp rate of increase in DSP receipt among public renters and their over-representation among the DSP population make this is a group that is particularly vulnerable to the impacts of Welfare to Work.

\section{Changing from DSP to the NSA regime}

All OECD countries have disability programs that provide cash benefits to disabled persons. Universal programs pay benefits to all disabled people (Sweden, Denmark), contributory programs pay benefits to disabled workers who make tax-based contributions (Austria, Canada), and non-contributory means-tested programs are targeted to groups in most need (Australia). Some countries have more than one type of

program. For example, the United Kingdom has contributory and non-contributory programs (Mont 2004). Both the DSP and NSA programs in Australia are noncontributory means-tested programs.

Under the Welfare to Work rules disabled welfare applicants from 1 July 2006 will only receive DSP if they are assessed as being incapable of 15 hours work a week. If assessed as being capable of at least 15 hours work, they will receive NSA and be obligated to seek part-time work. The preliminary estimate of the number of people diverted from DSP to NSA over three years are: 34,400 in $2006-07$; 57,900 in $2007-08$; and 75,700 in 2008-09 (Employment and Workplace Relations and Education Legislation Committee 2005).

The differences between the DSP and NSA regimes are illustrated in Figure 3. Firstly, DSP is a pension, while NSA is an allowance. Pensions are benefits paid to people 
expected to be indefinitely out of the labour force, such as the aged and disabled. Allowances are benefits paid to unwaged people seeking work or who are expected to return to work in the short-term (including persons with short-term sicknesses). Pensions are more generous than allowances. The current weekly maximum DSP rate for single (partnered) persons is approximately $\$ 40(\$ 20)$ higher than NSA $\left(S_{1}>S_{2}\right.$ in Figure 3). Second, the DSP income-free area (allowable income level before the benefit is reduced) is higher and increases by $\$ 24.60$ per fortnight per dependent child $\left(Y_{1}^{f}>Y_{2}^{f}\right)$. Hence, DSP recipients can earn up to a higher income level before their benefit is reduced. Third, DSP recipients experience a lower benefit withdrawal rate as private income increases. The DSP withdrawal rate is currently 40 cents (20 cents) in the dollar for single (partnered) persons. This means that for singles, DSP is withdrawn at 40 cents for each additional dollar earned past the income-free area. Once a NSA recipient's income exceeds the income-free area of $\$ 62$ per fortnight, NSA is reduced by 50 cents in the dollar. A second income test threshold applies at \$250 per fortnight. Income, which exceeds this second threshold, reduces NSA at a rate of 60 cents in the dollar. A partnered recipient's NSA is further reduced by 60 cents in the dollar once the partner's income exceeds the benefit cut-out point.

Figure 3 here

Because the DSP and NSA regimes interact with the tax and housing assistance systems, the impacts of a shift from DSP to NSA cannot be obtained from an analysis of the benefits alone. First, DSP is non-taxable while NSA is taxable. Hence, DSP recipients 
diverted onto NSA will face a decrease in disposable income if they do not gain employment. Second, public renters pay income-related rents, set at the lower of $25 \%$ of income or market rent. They receive housing assistance in the form of a housing subsidy equivalent to market rent minus income-related rent. When diverted onto NSA, public renters' income and therefore rent will fall, resulting in an increase in subsidy. Because of these interactions, a microsimulaton methodology is employed to assess the implications of diverting DSP applicants onto NSA. A microsimulaton model is a quantitative model that simulates tax-benefit parameters for a sample of individuals, frequently employed to predict the impacts of policies changes by setting alternative scenarios, varying the tax-benefit parameters and simulating the impacts of the change. It is a technique particularly suitable for finding accurate estimates in systems where the interactions within the system are complex. Examples include the United Kingdom Institute of Fiscal Studies' tax and benefit model (Giles \& McCrae 1995) and Canada’s Social Policy Simulation Database and Model (Statistics Canada 2006). In this paper estimates of the impacts of the change from DSP to NSA are derived using the Australian Housing and Urban Research Institute’s (AHURI) tax-benefit model (Wood et al. 2006b).

The AHURI tax-benefit model is operationalised using SIHC microdata, which contains cases that reflect the heterogeneity of the Australian population and is a rich source of income and housing data. While the Welfare to Work reforms were fully implemented in July 2006, the latest SIHC available at the time of writing of this paper was the 2002 SIHC. The methodology is based on the assumption that future (post-July 2006) DSP recipients have a profile similar to current (2002) DSP recipients. Using the model, we 
generate housing affordability and work incentive measures for current DSP recipients in the 2002 SIHC under the 2002 DSP regime. Next we simulate a policy change by assuming that all current DSP recipients are moved onto NSA. The model is used to compute the housing affordability and work incentive measures for all current DSP recipients as if the new NSA parameters described above in Figure 3 apply.

It must be stressed that this simulation does not demonstrate the actual impact of the reforms for new DSP applicants after July 2006. However, it does enable identification of groups whose housing affordability and work incentives are expected to be affected if we assume that the future profile of DSP recipients matches that of current DSP recipients, and if all future applicants are diverted into the NSA regime. As the number of SIHC cases available for analysis is rather small, we validate the SIHC estimates by producing a second set of estimates using the HILDA Survey for a comparable year ${ }^{6}$. The text commentary refers only to the 2002 SIHC. However, estimates from both surveys are reported in the tables, and similar observations can be drawn from both sets of estimates.

Both housing affordability and work incentive measures are based on income units. An income unit is different from the household because an income unit comprises one or more persons whose command over income is shared between the people comprising the unit (Australian Bureau of Statistics 1997). Income sharing is assumed to take place amongst couples, and between parents and dependents. A household comprises people who typically reside together, and can contain more than one income unit. In Australia the income unit is the standard unit for analyses of economic well-being. It is often the 
preferred approach in Australian housing studies (Landt \& Bray 1997; Wood et al. 2006a). DSP income units are income units in which at least one income unit member receives DSP.

\section{Impacts on housing affordability}

In Australia income units are in housing stress if they are in the bottom $40 \%$ of the gross income distribution and pay more than $30 \%$ of gross income on housing (National Housing Strategy 1991). In 2002, 81\% of DSP income units were in the bottom $40 \%$ of the income distribution compared to $37 \%$ of non-DSP income units ${ }^{7}$. Hence, there are clear housing affordability implications for DSP applicants diverted onto NSA who do not find work. While the DSP and NSA regimes do not differ across tenure, their interactions with the housing assistance systems mean that the impacts of diverting DSP recipients onto NSA can be significantly different across tenure groups.

We employ three measures to quantify the differential impacts of the policy simulation across housing tenures. First, we compare before- and after-housing income. Second, we calculate a housing affordability ratio, which expresses housing costs as a percentage of income unit income. Third, we measure the percentage of income units in housing stress under the alternative regimes. Housing costs for outright owners are general and water rates; for purchasers rates and mortgage repayments; for private renters rent less CRA; and for public renters income-related rents. Any housing assistance received is treated as an offset against housing costs, not as part of income. Hence, our affordability ratio is a net affordability ratio (NAR). In this section, income is equivalised using OECD 
equivalence scales that allocate 1 for the first adult, 0.7 for each additional adult and 0.5 for each child. The simulation results are reported in Table 1.

\section{Table 1 here}

Table 1 shows that for owners, housing costs do not change following the policy change. For private renters, housing costs increase slightly. This is because a small percentage of private renters who receive DSP would not be eligible for NSA in the new regime because the NSA cut-out point is lower than the DSP cut-out point. Hence, they will not receive CRA because CRA is paid as a supplement to government benefits. Public renters experience a substantial fall in housing costs because rents are income-related.

Private renters experience the greatest increase in average NAR of 4.5 percentage points following the policy change. The housing stress figures support the NAR findings, with private renters experiencing the greatest rise in proportion in housing stress following the

policy change. In recent decades there has been a pronounced decline in housing affordability for low-income private renters (Yates 2005; Yates et al. 2004; Wood et al. 2005a). Private renters diverted onto NSA will receive less income and experience a reduced housing affordability. Private renters pay market rent and receive housing assistance in the form of a cash benefit called Commonwealth Rent Assistance (CRA). Both DSP and NSA recipients are eligible for CRA but the level of CRA received is dependent on the market rent level rather than income level. Hence, while private renters will experience a decrease in income, they will not benefit from an increase in CRA as 
long as rent remains the same. The change from DSP to NSA therefore has potentially significant negative implications for private renters' housing affordability levels.

Owner purchasers have the highest housing costs because of mortgage repayments. However, as opposed to private renters, purchasers experience little change in the level of housing stress following the policy change despite high housing costs. Purchasers' average after-housing income is almost twice the average of all tenures. This is not surprising as over one-third of DSP purchaser income units are employed, compared to under $15 \%$ of the other tenures. In the 2002 HILDA Survey, one-quarter of DSP private renter income units reported inability to pay rent on time, while only $16 \%$ of DSP purchaser income units reported that they could not pay their mortgage on time. Moreover, the extent of purchasers' decline to housing affordability will depend a great deal on the length of time they have been purchasers. Purchasers in the early period of mortgage, especially first home purchasers, typically pay a large proportion of income in repayments. In later years repayments are likely to form a smaller proportion of income. If the age profile of purchasers who apply for DSP is the same as the current profile of DSP recipients it is likely that most will be in the later years of the mortgage and therefore experience a moderate decline in housing affordability.

Outright owners experience almost no change in housing affordability. Outright owners do not make mortgage repayments and therefore have low housing costs. Low-income outright owners traditionally experience few housing affordability problems. 
Public renters typically pay income-related rent set at 25\% of income and almost all have such low incomes that mean they do not pay the median market rent. Consequently when public renters are diverted onto NSA their rent will fall and the level of subsidy will increase. This is happening in a housing sector that is very constrained as Australian government funding for public housing has declined by one-quarter in real terms over the

period 1990-2000 (Hall \& Berry 2004). This has been a result of the government's decision to increasingly use CRA to provide housing assistance to low income Australians. The result has been increased rationing of public housing stock and an increasing proportion of public housing eligible persons being forced to rent privately. Moreover, it is important to note that this change will reduce SHA revenue. Already the combined effect of reducing grant income and declining tenant incomes has resulted in SHAs incurring structural deficits (Hall \& Berry 2004). The introduction of this new regime will further undermine SHA financial viability. SHAs will experience rent revenue loss as existing DSP recipients move out of public housing and are replaced by tenants who apply for DSP but are judged to be able to work at least 15 hours per week ${ }^{8}$. If we assume that all DSP recipients in public housing in 2002 were moved onto NSA, SHA rent income would be reduced by $\$ 33$ million.

\section{Impacts on work disincentives}

In order to quantify the work incentives facing DSP recipients who are unemployed or economically inactive (unwaged), we measure and compare the replacement ratio (RR) under the DSP and NSA regimes using the microsimulation model and Wood et al. 
(2005b) RR methodology ${ }^{9}$. The RR is the ratio of income when unwaged to income when employed. The higher is the RR the lower are the financial returns to work.

The RR of person $i$ is

$$
\begin{aligned}
& R_{i}=Y_{i}^{n} / Y_{i}^{w} \\
& \text { where } R_{i}=\text { RR of person } i \\
& Y_{i}^{n}=\text { income unit disposable income when person } i \text { is not working } \\
& Y_{i}^{w}=\text { income unit disposable income when person } i \text { is working. }
\end{aligned}
$$

RRs are computed for each unwaged individual holding the employment status of the partner (if there is one) constant. Hence, in the case of a couple income unit where one partner is employed but the other is not, we calculate the RR for the unwaged partner only, holding the waged partner's employed status constant. Where both partners are unwaged, we calculate a RR for the first unwaged partner holding the second's unwaged status constant and then separately calculate a RR for the second partner holding the first' unwaged status constant. This is done because the expected wage of each individual is likely to be different resulting in different RRs for partners within an income unit. As in the case of housing affordability, the income measures in the numerator and denominator of the RR are income unit income. Because partners within an income unit share income, the work incentive of a partnered person will be affected by his/her income unit's income rather than his/her income alone. For example, in the first case where one partner is employed but the other is not, the employed partner's wage will cushion the unwaged partner's economic well-being, hence blunting the unwaged partner's work incentives. 
Importantly, the microsimulation model allows Australian tax provisions and income support parameters to be taken into account in both $Y_{i}^{n}$ and $Y_{i}^{w}$. Even when an unwaged person gains employment, he/she is still eligible to receive benefits at a reduced rate if income is low. Wage estimates are derived from wage equations that have been estimated from samples of working age male and female employees. The equations control for selection bias using the Heckman correction and are reported in Table 2.

Table 2 here

Table 3 presents RR estimates by housing tenure in terms of mean and median RRs together with the percentage of persons with RRs greater than 75\%.

Table 3 here

Table 3 shows that overall RRs are 6-9 percentage points higher under the NSA regime than the DSP regime. In other words the financial disincentive, regardless of tenure, will be greater under the NSA regime. This is mainly due to NSA being less generous than DSP. As Figure 3 shows, NSA provides a lower level of benefit income than DSP. As most unwaged DSP recipients would attract low wages if employed, most would still be entitled to part payments of benefits in an employed state ${ }^{10}$. NSA has a lower income-free threshold and higher withdrawal rates than DSP. Hence, when an unwaged DSP recipient moves into employment, he/she loses a higher level of government benefit payment 
under the NSA regime than the DSP regime. The mean benefit level received by unwaged DSP recipients under the DSP regime is \$10,619 and approximately 11\% lower at $\$ 9,447$ under the NSA regime. The mean benefit level received by DSP recipients, if they gain employment, is $\$ 6,191$ under the DSP regime, but three times as low at $\$ 2,168$ under the NSA regime.

DSP recipients in public housing have higher RRs than DSP recipients in other tenures. Hence, public renters experience the lowest returns to employment of all DSP recipients. This is mainly attributed to the withdrawal of housing subsidy that accompanies any gain in employment (Dalton \& Ong 2005). The simulation indicates that the proportion of public renters experiencing a RR greater than $75 \%$ will increase from $21 \%$ to $65 \%$, indicating a tripling in the proportion of public renters whose income while not employed is over three-quarters of the income they can expect to receive on gaining employment ${ }^{11}$. While unwaged owner purchasers have relatively high RRs, this is largely because of their partners' income, which cushion their decline in economic well-being while they remain unwaged. Over three-quarters of unwaged purchasers are partnered and among these, 34\% have employed partners. In contrast, under one-quarter of public renters in our sample have partners and among these only 6\% have employed partners. Further, the data show, but not presented in this article, that females typically have a higher RR than males under both the DSP and NSA because they attract a lower wage than males if they were to gain employment. 
Lastly, the RR estimates suggest that this new policy will run counter to another government policy objective, which aims to increase public renters' employment participation. The CSHA requires SHAs 'to ensure that housing assistance supports access to employment and promotes social and labour market participation' (Commonwealth of Australia 2003). This SHA responsibility is likely to become more onerous.

\section{Individuals, housing affordability and work disincentives}

Finally, we illustrate the effect of Welfare to Work for two real-life cases to illustrate what the policy change means to individuals from interview data obtained from two current DSP recipients, a private renter and a public renter. As indicated by our empirical analysis, private renters face substantial housing affordability problems while public renters suffer from high work disincentives, which are likely to be exacerbated by the policy change. We assumed that they were applying for DSP post-July 2006 and were judged capable of working at least 15 hours per week. The model was used to calculate their housing affordability levels and RRs under the two regimes:

- Case 1 is a single male private renter, economically inactive since the late 1990s, pays \$140 rent per week and receives CRA;

- Case 2 is a partnered male public renter, economically inactive since 2002. His partner is working part-time and receiving NSA at a reduced rate.

Case 1 , under the DSP regime, has a NAR of $44 \%$. Being in the lowest $40 \%$ of the income distribution he is in housing stress. As expected, housing affordability for Case 1 
declines when moved to the NSA regime, indicated by a NAR increase to $51 \%$. Under the NSA regime, half of Case 1's income would be spent on housing costs, leaving little income for other necessities, including additional medical costs that disabled often have to meet. For Case 2 the NAR stays the same at $14 \%$ because rent is set at $25 \%$ of income. However, Case 2 has higher work disincentives than Case 1 because of a rapid withdrawal of rent subsidy as income increases. The RRs indicates that Case 1's RR increases from $60 \%$ to $67 \%$ when moved from DSP to NSA. Case 2's RR increases from $71 \%$ to $80 \%$. Under NSA, Case 2's income when unwaged is fourth-fifth of expected income when employed. After taking into account work-related expenditures such as transport costs that are not reflected in the RR, Case 2 will find returns to work to be extremely low.

\section{Conclusion}

This paper has presented an analysis of the connection between housing and the DSP. Its starting point was the observation that the Welfare to Work policy regime which will result in DSP applicants being redirected onto NSA, with accompanying economic requirements, does not take account of the housing circumstances of these future DSP applicants. In this context two questions were posed.

The first question asked: 'What are the housing circumstances of working age DSP recipients?' The evidence shows a distinctive pattern in the distribution of DSP recipients across housing tenures. DSP recipients who are outright owners and private renters stand out as the two largest groups in 2002 by comprising 36\% and 30\% of all DSP recipients 
respectively (see section 3). However, the tenure most over-represented among the DSP population is public housing. Whereas public renters were only $3 \%$ of the working age population in 2002, the percentage of public renters among the DSP population was six times as high at 19\%. The high rate of DSP receipt among public renters in 2002 (27\% in figure 2) and their over-representation among the DSP population make this a group particularly vulnerable to Welfare to Work.

In the light of this pattern a second question asked: 'What are the likely consequences of announced program changes aimed at increasing labour market participation of DSP applicants diverted onto NSA?' The following can be drawn from the analysis. The proposed changes will have the greatest impact on renters, both private and public. First, private renters applying for DSP and diverted onto NSA will have less income and experience a decline in housing affordability. CRA is ineffective in mitigating the affordability decline, as the level of CRA payment is dependent on the market rent paid and not on income level. Second, while public renters currently have the impact of the change moderated because of income-related rents, increased rationing of public housing stock will force many future public housing eligible persons to rely on the private rental market for housing, putting them at risk of substantial affordability problems. Third, an unintended consequence of the policy change will be a reduction in SHA revenue that will exacerbate existing structural deficits. Fourth, the NSA regime will lower the financial return to work for future DSP applicants in all tenures, evident in the increase in RR for income units in each tenure. Public renters who are DSP recipients currently 
experience the lowest financial return to work and this will be exacerbated under the new system.

Currently there appears to be a trade-off between housing affordability and financial returns to work for renters. While public renters usually do not have housing affordability problems they face high work disincentives. While private renters' RRs are low relative to public renters, they suffer from severe housing affordability problems. Welfare to Work will intensify affordability problems and reduce financial returns to work. Private and public renters are especially vulnerable groups in the context of Welfare to Work. The Australian experience can be used to sound a cautionary note to policy makers in other OECD countries seeking to constrain disability payments and increase labour market participation. It is important to consider the way in which housing interacts with income support systems, tax and labour market income if national goals are to extend beyond economic goals and include fairness. 


\section{Bibliography}

Argyrous, G. and Neale, M. 2001, Labor market disability: implications for the unemployment rate., In Economic and Labour Relations Review, Vol. 12, pp. (263)-284.

Australian Bureau of Statistics 1997, Survey of Income and Housing Costs Australia: User Guide, 6553.0, Australian Bureau of Statistics, Canberra,

Australian Council of Social Service 2005, Welfare reform: participation or punishment?, ACOSS Info 373, Sydney, http://www.acoss.org.au

Australian Government 2005, Welfare to Work, Budget Related Papers, 10 May 2005, Canberra, http://www.budget.gov.au

Berry, M., Murphy, J., Nygaard, C. and Wood, G. 2005, Winners and losers: regional futures and local profiles: A Report to the Salvation Army Melbourne Central Division, Centre for Applied Social Research and RMIT / NATSEM Research Centre of the Australian Housing and Urban Research Institute. RMIT University, Melbourne,

Cai, L. 2002, Length of completed spells on the Disability Support Pension (DSP) program, In Australian Social Policy (Canberra, ACT), pp. 101-120.

Cai, L. and Gregory, R. 2002, Inflows, outflows and the growth of the Disability Support Pension (DSP) program, In Australian Social Policy, pp. 121-143.

Cai, L. and Gregory, R. G. 2004, 'Labour market conditions, applications and grants of Disability Support Pension (DSP) in Australia', Australian Journal of Labour Economics, Vol.7, No.3, pp.375-394.

Cass, B., Goibson, F. and Tito, F. 1988, Towards Enabling Policies: Income Support for People with Disabilities, Social Security Review, Australian Government Publishing Service, Canberra,

Castles, F. 1997, 'Leaving the Australian Labour Force: An Extended Encounter with the State', Governance, Vol.10, No.2, pp.1-22.

Chalmers, J. and Siminski, P. 2003, Flows onto the Disability Support Pension, An Analysis of the ABS Survey of Disability Ageing and Carers 1998 and the FaCS Longitudinal Administrative Data, Final Report, Social Policy Research Centre, University of New South Wales, Sydney,

Commonwealth of Australia 2003, Housing Assistance (Form of Agreement)

Determination 2003, Commonwealth of Australia Gazette No. S 276 Thursday 17 July 2003, 15 July 2003,

Community Affairs Legislation Committee 2005, Provisions of the: Employment and Workplace Relations Legislation Amendment (Welfare to Work and Other Measures) Bill 2005 and Family and Community Services Legislation Amendment (Welfare to Work) Bill 2005, Parliament of the Commonwealth of Australia, Canberra,

Dalton, T. and Ong, R. 2005, 'Precarious employment in the urban context: the case of public housing', Just Policy: A Journal of Australian Social Policy, No.37, pp.4249.

Employment and Workplace Relations and Education Legislation Committee 2005, Increased workforce participation, Question number: W016-06, Senate 
Employment, Workplace Relations and Education Committee, Senate, Parliament of Australia, http://www.aph.gov.au/Senate/committee/eet_ctte/estimates/bud_0506/dewr/index. $\underline{\mathrm{htm}}$

Evaluation and Programme Performance Branch Employment Analysis and Evaluation Group 2004, Job Network Disability Support Pension Pilot: Interim Evaluation Report, October 2004, Department of Employment and Workplace Relations, Canberra, http://www.dewr.gov.au/

Galvin, R. 2003, The function of language in the creation and liberation of disabled identities: from Saussure to contemporary strategies of government., In Australian Journal of Communication, Vol. 30, pp. 83-100.

Galvin, R. 2004, Can welfare reform make disability disappear?, In Australian Journal of Social Issues, Vol. 39, pp. 343-355.

Giles, C. and McCrae, J. 1995, TAXBEN: the IFS Microsimulation Tax and Benefit Model, Working Paper W95/19, Institute of Fiscal Studies, London, http://www.ifs.org.uk/

Hall, J. and Berry, M. 2004, Operating deficits and public housing: policy options for reversing the trend, Australian Housing and Urban Research Institute, Melbourne, www.ahuri.edu.au

Healy, E. 2002, 'Disability' or 'disadvantage': spatial variation in the Disability Support Pension recipient rate 1996-2001., In People and Place, Vol. 10, pp. 68-83.

House of Representatives Standing Committee on Employment Workplace Relations and Workforce Participation 2005, Working for Australia's future: Increasing participation in the workforce, March 2005, The Parliament of the Commonwealth of Australia, Canberra, http://www.aph.gov.au/house/committee/ewrwp/reports.htm

Landt, J. and Bray, R. 1997, Alternative Approaches to Measuring Rental Housing Affordability in Australia, Discussion Paper No. 16, National Centre for Social and Economic Modelling, University of Canberra, Canberra,

Lattimore, R. 2007, Men Not at Work: An Analysis of Men Outside the Labour Force, Staff Working Paper, Productivity Commission, Melbourne,

Mont, D. 2004, Disability Employment Policy, Social Protection Discussion Paper Series, No 0413, World Bank, Washington, http://www.worldbank.org/sp

Morrow, I. 2000, The internal migration of Disability Support Pension recipients: findings from the FaCS Longitudinal Data Set, In Australian Social Policy (Canberra, ACT), pp. 55-86.

National Housing Strategy 1991, The affordability of Australian housing, Issues Paper No. 2, Edwards, M., Australian Government Publishing Service, Canberra.

OECD 2003, Transforming Disability into Ability Policies to Promote Work and Income Security for Disabled People, Organisation for Economic Co-operation and Development, Paris,

Office of Disability 2004, Characteristics of Disability Support Pension Customers, June 2004, Department of Family and Community Services, Canberra, http://www.jobable.gov.au/

Parliament of Australia 2005, Employment and Workplace Relations Legislation Amendment (Welfare to Work and Other Measures) Act 2005, No. 154, 2005, http://scaleplus.law.gov.au/cgi-bin/download.pl?/scale/data/comact/12/7068/ 
Saunders, P. 2005, Disabiltiy, Poverty and Living Standards: Reviewing Australian Evidence and Policies, SPRC Discussion Paper No. 145, Social Policy Research Centre, Sydney,

Statistics Canada 2006, The Social Policy Simulation Database and Model (SPSD/M), Statistics Canada, Ottawa, http://www.statscan.net/english/spsd/spsdm.htm

Wilkins, R. 2004, 'The effects of disability on labour force status in Australia', Australian Economic Review, Vol.37, No.4, pp.359-382.

Wood, G., Berry, M., Dalton, T., Pettit, C., Allan, I., Leong, K. and Stokes, A. 2005a, Affordable Housing for low Income Victorians: A Summary of a Report on Research on Recent Trends and Issues in Affordable Housing Carried out For the Victorian Department of Premier and Cabinet, AHURI, RMIT University, Melbourne,

Wood, G., Ong, R., Dockery, A. M. and Flatau, P. 2005b, Housing Assistance Programmes and Their Contribution to Poverty and Unemployment Traps, National Research Venture 1: Housing Assistance and Economic Participation, Research Paper 1., Australian Housing and Urban Institute, Melbourne,

Wood, G., Watson, R. and Flatau, P. 2006a, 'Low Income Housing Tax Credit Programme Impacts on Housing Affordability in Australia: Microsimulation Model Estimates', Housing Studies, Vol.21, No.3, pp.361-380.

Wood, G. A., Watson, R. and Flatau, P. 2006b, 'Microsimulation Modelling of Tenure Choice and Grants to Promote Home Ownership', Australian Economic Review, Vol.29, No.1, pp.14-34.

Yates, J. 2005, 'Market Provision of Affordable Rental Housing: Lessons from Recent Trends in Australia', Urban Policy and Research, Vol.23, No.1, pp.5-19.

Yates, J., Wulff, M. and Reynolds, M. 2004, Changes in the supply of and need for low rent dwellings in the private rental market, Australian Housing and Urban Research Institute, Melbourne,

${ }^{1}$ Non-dependent persons aged 15-64.

${ }^{2}$ Neither working nor seeking work.

3 Authors' calculations from the 2002 Survey of Income and Housing Costs (SIHC). All 2002 estimates in the text are from authors' calculations from the 2002 SIHC unless stated otherwise.

4 The maximum DSP rate is currently approximately \$40 per week higher than the maximum Newstart rate for a single person without children.

${ }^{5}$ Contractions in the stock of low-income rental housing have been documented in other countries. Examples include Park (2000) from the United States, and Miron (1995) from Canada.

${ }^{6}$ Estimates from the 2002 SIHC are based on current 2002 weekly income. Estimates from the HILDA Survey are based on 2002-03 financial year income.

${ }^{7}$ Income units with negative or zero gross income unit income are removed.

${ }^{8}$ In 2005 the number of new households entering public housing as a percentage of total number of public renters was 9.5\% (Australian Institute of Health and Welfare 2005:43). Data from earlier years indicate a similar rate of change.

${ }^{9} 93 \%$ of DSP recipients in 2002_were unwaged.

${ }^{10}$ The mean wage that an unwaged DSP recipient would attract upon gaining employment is only $\$ 18,900$ compared to \$22,900 for an unwaged person not receiving DSP_in 2002. 
Welfare to Work in Australia: disability income support, housing affordability and employment incentives

${ }^{11}$ As shown by the median RRs in Table 3, the average public renter already has a RR of 70\% under the DSP regime. When moved onto NSA, the average public renter's RR rises over the $75 \%$ benchmark, to $78 \%$. 
Welfare to Work in Australia: disability income support, housing affordability and employment incentives

\section{Tables and figures for}

Welfare to Work in Australia:

disability income support, housing affordability and employment incentives

Figure 1: DSP recipients, 1972-2002

Figure 2: Percentage of DSP recipients by housing tenure, 1982-2002

Figure 3: The DSP and NSA systems

Table 1: Housing affordability of DSP income units, under DSP and NSA systems, 2002-03

Table 2: Wage regression estimates, males and females, 2002

Table 3: RRs of unwaged DSP recipients ${ }^{\mathrm{a}}$, under existing DSP and NSA systems, 2002-03, percent 
Figure 1: DSP recipients, 1972-2002

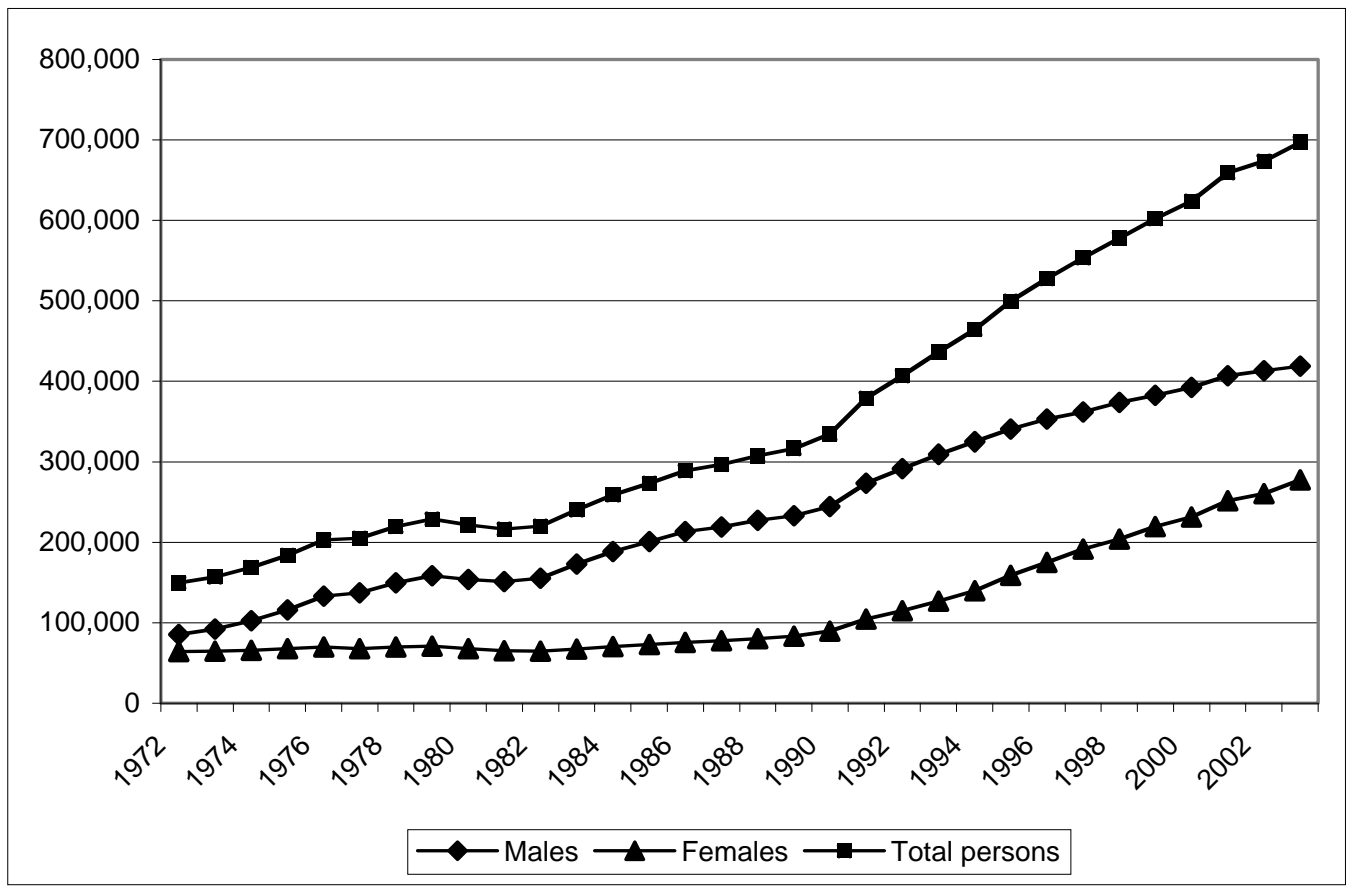

Source: Office of Disability (2004) 
Figure 2: Percentage of DSP recipients by housing tenure, 1982-2002

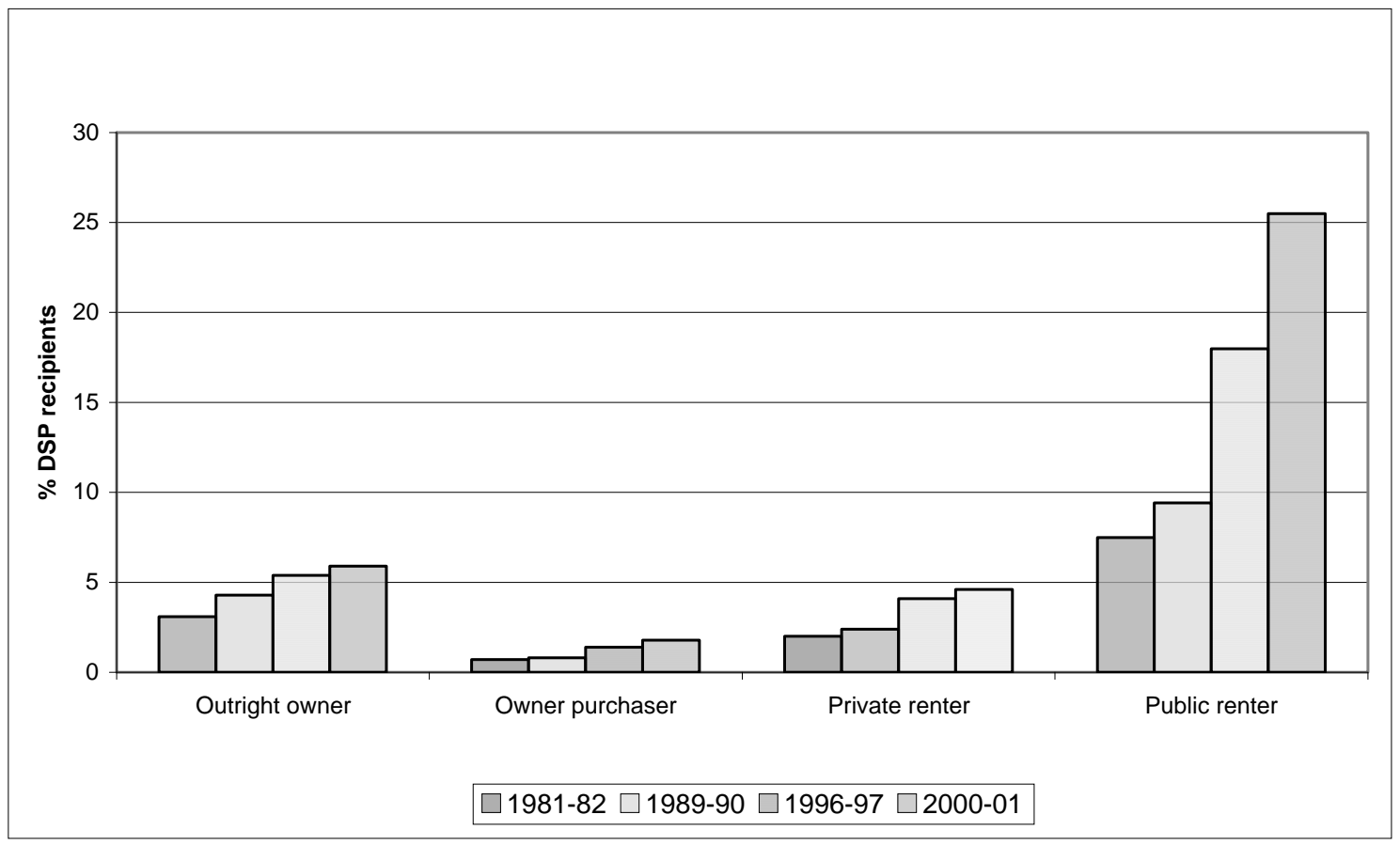

Source: 1982 SIHC, 1990 SIHC, 2002 SIHC 
Figure 3: The DSP and NSA systems

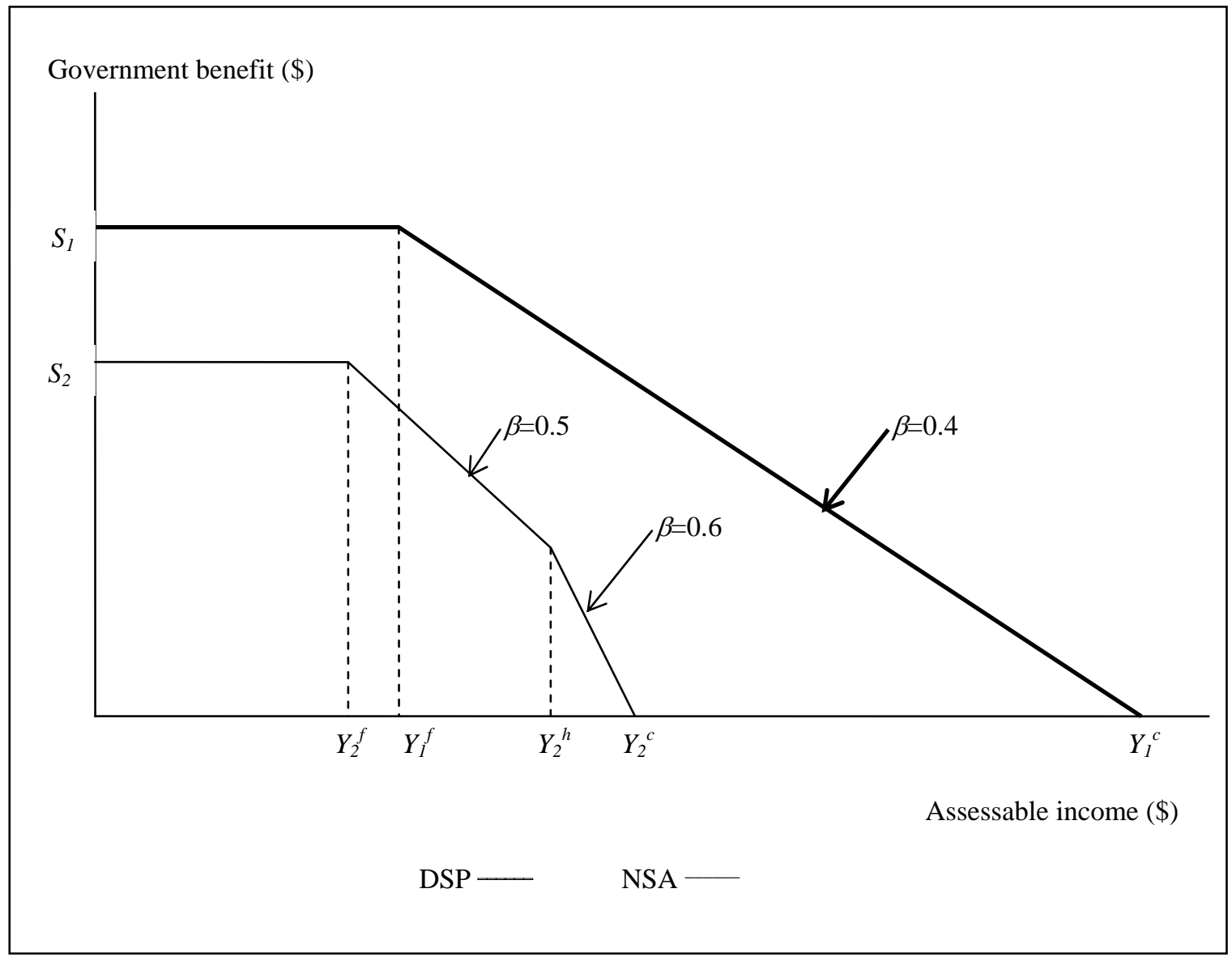


Table 2: Housing affordability of DSP income units ${ }^{\mathrm{a}}$, under DSP and NSA systems, 2002-03

\begin{tabular}{|c|c|c|c|c|c|c|c|c|c|c|}
\hline \multirow{2}{*}{$\begin{array}{c}\text { Survey } \\
\text { Scenario }\end{array}$} & \multicolumn{5}{|c|}{ SIHC } & \multicolumn{5}{|c|}{ HILDA Survey } \\
\hline & $\begin{array}{c}\text { Outright } \\
\text { owner }\end{array}$ & $\begin{array}{c}\text { Owner } \\
\text { purchaser }\end{array}$ & $\begin{array}{c}\text { Private } \\
\text { renter }\end{array}$ & $\begin{array}{l}\text { Public } \\
\text { renter }\end{array}$ & Total & $\begin{array}{c}\text { Outright } \\
\text { owner }\end{array}$ & $\begin{array}{c}\text { Owner } \\
\text { purchaser }^{b}\end{array}$ & $\begin{array}{l}\text { Private } \\
\text { renter }\end{array}$ & $\begin{array}{l}\text { Public } \\
\text { renter }\end{array}$ & Total \\
\hline \multicolumn{11}{|c|}{ Mean housing cost (dollars per year) } \\
\hline DSP & 989 & 6,387 & 3,522 & 2,890 & 2,846 & 0 & 6,581 & 4,165 & 3,281 & 2,979 \\
\hline NSA & 989 & 6,387 & 3,548 & 2,635 & 2,800 & 0 & 6,581 & 4,241 & 3,037 & 2,943 \\
\hline Percentage change & 0.0 & 0.0 & 0.7 & -8.8 & -1.6 & & 0.0 & 1.8 & -7.4 & -1.2 \\
\hline \multicolumn{11}{|c|}{ Mean before-housing cost income (dollars per year) } \\
\hline DSP & 28,785 & 48,492 & 20,154 & 19,082 & 26,479 & 37,592 & 45,404 & 30,911 & 24,213 & 33,589 \\
\hline NSA & 27,057 & 46,040 & 18,519 & 17,777 & 24,780 & 34,588 & 42,927 & 28,681 & 22,904 & 31,296 \\
\hline Percentage change & -6.0 & -5.1 & -8.1 & -6.8 & -6.4 & -8.0 & -5.5 & -7.2 & -5.4 & -6.8 \\
\hline \multicolumn{11}{|c|}{ Mean after-housing cost income (dollars per year) } \\
\hline DSP & 27,796 & 42,105 & 16,633 & 16,192 & 23,633 & 37,592 & 38,823 & 26,746 & 20,931 & 30,610 \\
\hline NSA & 26,068 & 39,653 & 14,971 & 15,143 & 21,980 & 34,588 & 36,346 & 24,440 & 19,867 & 28,353 \\
\hline Percentage change & -6.2 & -5.8 & -10.0 & -6.5 & -7.0 & -8.0 & -6.4 & -8.6 & -5.1 & -7.4 \\
\hline \multicolumn{11}{|l|}{ Average NAR (percent) } \\
\hline DSP & 4.7 & 20.8 & 23.8 & 21.0 & 16.1 & 0.0 & 24.9 & 21.8 & 19.2 & 14.7 \\
\hline NSA & 5.3 & 22.5 & 28.3 & 21.2 & 17.9 & 0.0 & 28.1 & 25.6 & 19.2 & 16.2 \\
\hline Percentage point difference & 0.5 & 1.7 & 4.5 & 0.2 & 1.8 & 0.0 & 3.2 & 3.7 & 0.0 & 1.6 \\
\hline \multicolumn{11}{|c|}{ Percentage in housing stress (percent) } \\
\hline DSP & 0.0 & 16.5 & 23.9 & 1.4 & 9.8 & 0.0 & 27.7 & 23.0 & 1.0 & 11.1 \\
\hline NSA & 0.5 & 17.7 & 27.9 & 3.1 & 11.7 & 0.0 & 30.8 & 28.7 & 1.0 & 13.2 \\
\hline Percentage point difference & 0.5 & 1.2 & 4.0 & 1.7 & 1.9 & 0.0 & 3.1 & 5.7 & 0.0 & 2.1 \\
\hline \multicolumn{11}{|l|}{ Number of cases } \\
\hline Sample ${ }^{\mathrm{c}}$ & 191 & 65 & 166 & 128 & 550 & 84 & 48 & 99 & 74 & 305 \\
\hline Population ('000s) ${ }^{\mathrm{d}}$ & 144 & 50 & 127 & 86 & 408 & 115 & 53 & 105 & 86 & 358 \\
\hline
\end{tabular}

Source: Authors' calculations from the 2002 SIHC and HILDA Survey wave 3 Notes:

a. The sample comprises DSP income units.

b. The HILDA Survey does not contain data on general and water rates. Hence, housing costs for owners exclude rates.

c. Estimates for owner purchasers need to be interpreted with caution given the small sample size of this group.

d. Estimates are weighted by population weights or expansion factors to produce estimates for the whole population. This procedure ensures that the survey estimates conform to benchmarks that are based on the numbers of persons and households in the Australian population. 
Table 3: Wage regression estimates, male and female employees, 2002

\begin{tabular}{|c|c|c|c|c|c|c|}
\hline Explanatory variables & Coef. & $\begin{array}{c}\text { Std. } \\
\text { error }\end{array}$ & Sig. & Coef. & $\begin{array}{c}\text { Std. } \\
\text { error }\end{array}$ & Sig. \\
\hline \multicolumn{7}{|c|}{ SIHC (dependent variable is log of current weekly annualised wage) } \\
\hline & \multicolumn{3}{|c|}{ Males } & \multicolumn{3}{|c|}{ Females } \\
\hline Constant & 5.802 & 0.049 & 0.000 & 5.790 & 0.063 & 0.000 \\
\hline \multicolumn{7}{|l|}{ Age (15-19 omitted) } \\
\hline $20-24$ & 0.303 & 0.048 & 0.000 & 0.229 & 0.059 & 0.000 \\
\hline $25-34$ & 0.524 & 0.052 & 0.000 & 0.480 & 0.056 & 0.000 \\
\hline $35-44$ & 0.595 & 0.061 & 0.000 & 0.514 & 0.058 & 0.000 \\
\hline $45-54$ & 0.594 & 0.071 & 0.000 & 0.379 & 0.060 & 0.000 \\
\hline $55-64$ & 0.405 & 0.106 & 0.000 & -0.041 & 0.095 & 0.664 \\
\hline Married/de facto & 0.185 & 0.025 & 0.000 & -0.031 & 0.022 & 0.159 \\
\hline Number of dependent children aged 0-2 & -0.003 & 0.024 & 0.908 & -0.340 & 0.052 & 0.000 \\
\hline Number of dependent children aged 3-4 & 0.061 & 0.031 & 0.044 & -0.302 & 0.048 & 0.000 \\
\hline Number of dependent children aged 5-9 & 0.021 & 0.019 & 0.259 & -0.221 & 0.029 & 0.000 \\
\hline Number of dependent children aged 10-14 & -0.007 & 0.016 & 0.679 & -0.138 & 0.020 & 0.000 \\
\hline \multicolumn{7}{|l|}{ Country of birth (Australia omitted) } \\
\hline Main English-speaking countries & 0.074 & 0.025 & 0.003 & 0.029 & 0.031 & 0.338 \\
\hline Other & -0.223 & 0.027 & 0.000 & -0.254 & 0.041 & 0.000 \\
\hline \multicolumn{7}{|c|}{ Highest educational qualification (no post-school qualification omitted) } \\
\hline Still at school & -1.917 & 0.431 & 0.000 & -1.058 & 0.382 & 0.006 \\
\hline Bachelor degree or higher & 0.493 & 0.036 & 0.000 & 0.678 & 0.040 & 0.000 \\
\hline Other post-school qualification & 0.128 & 0.018 & 0.000 & 0.226 & 0.028 & 0.000 \\
\hline \multicolumn{7}{|l|}{ Location (Territories omitted) } \\
\hline Sydney & 0.044 & 0.039 & 0.255 & -0.125 & 0.045 & 0.006 \\
\hline Rest of New South Wales & -0.168 & 0.056 & 0.003 & -0.549 & 0.064 & 0.000 \\
\hline Melbourne & 0.003 & 0.035 & 0.933 & -0.190 & 0.042 & 0.000 \\
\hline Rest of Victoria & -0.239 & 0.055 & 0.000 & -0.449 & 0.063 & 0.000 \\
\hline Brisbane & -0.113 & 0.041 & 0.006 & -0.299 & 0.048 & 0.000 \\
\hline Rest of Queensland & -0.172 & 0.047 & 0.000 & -0.407 & 0.055 & 0.000 \\
\hline Adelaide & -0.118 & 0.044 & 0.007 & -0.259 & 0.047 & 0.000 \\
\hline Rest of South Australia & -0.136 & 0.065 & 0.038 & -0.486 & 0.074 & 0.000 \\
\hline Perth & -0.036 & 0.044 & 0.411 & -0.339 & 0.046 & 0.000 \\
\hline Rest of Western Australia & -0.086 & 0.056 & 0.124 & -0.552 & 0.069 & 0.000 \\
\hline
\end{tabular}




\begin{tabular}{|c|c|c|c|c|c|c|}
\hline Explanatory variables & Coef. & $\begin{array}{c}\text { Std. } \\
\text { error }\end{array}$ & Sig. & Coef. & $\begin{array}{c}\text { Std. } \\
\text { error }\end{array}$ & Sig. \\
\hline Hobart & -0.191 & 0.065 & 0.003 & -0.322 & 0.074 & 0.000 \\
\hline Rest of Tasmania & -0.176 & 0.056 & 0.002 & -0.610 & 0.072 & 0.000 \\
\hline Number of months unemployed in last seven months & -0.252 & 0.055 & 0.000 & -0.318 & 0.044 & 0.000 \\
\hline Number of months economically inactive in last seven months & -0.364 & 0.091 & 0.000 & -0.548 & 0.074 & 0.000 \\
\hline Lambda & 0.414 & 0.195 & 0.034 & 0.866 & 0.168 & 0.000 \\
\hline Sample & \multicolumn{3}{|c|}{5,011} & \multicolumn{3}{|c|}{4,392} \\
\hline Adjusted R-sq & \multicolumn{3}{|c|}{0.265} & \multicolumn{3}{|c|}{0.225} \\
\hline $\mathrm{P}>\mathrm{F}$ & \multicolumn{3}{|c|}{0.000} & \multicolumn{3}{|c|}{0.000} \\
\hline \multicolumn{7}{|c|}{ HILDA Survey (dependent variable is log of financial year wage) } \\
\hline & \multicolumn{3}{|c|}{ Males } & \multicolumn{3}{|c|}{ Females } \\
\hline Constant & 9.549 & 0.089 & 0.000 & 9.099 & 0.229 & 0.000 \\
\hline \multicolumn{7}{|l|}{ Marital status (Single never married omitted) } \\
\hline Married/de facto & 0.400 & 0.043 & 0.000 & 0.050 & 0.070 & 0.478 \\
\hline Divorced, separated or widowed & 0.150 & 0.066 & 0.024 & 0.069 & 0.097 & 0.478 \\
\hline \multicolumn{7}{|l|}{ Highest educational qualification (Year 11 and below omitted) } \\
\hline Year 12 & 0.095 & 0.051 & 0.063 & 0.312 & 0.097 & 0.001 \\
\hline Certificate not defined & 0.021 & 0.320 & 0.949 & 0.049 & 0.231 & 0.832 \\
\hline Certificate I or II & -0.398 & 0.153 & 0.009 & -0.492 & 0.179 & 0.006 \\
\hline Certificate III or IV & 0.197 & 0.042 & 0.000 & 0.374 & 0.103 & 0.000 \\
\hline Diploma or advanced diploma & 0.200 & 0.054 & 0.000 & 0.452 & 0.098 & 0.000 \\
\hline Bachelor degree & 0.393 & 0.051 & 0.000 & 0.750 & 0.138 & 0.000 \\
\hline Graduate diploma or graduate certificate & 0.447 & 0.070 & 0.000 & 0.832 & 0.145 & 0.000 \\
\hline Postgraduate degree & 0.520 & 0.073 & 0.000 & 0.984 & 0.166 & 0.000 \\
\hline Months in paid work since left full-time education & 0.007 & 0.001 & 0.000 & 0.007 & 0.001 & 0.000 \\
\hline Square of months in paid work since left full-time education & 0.000 & 0.000 & 0.000 & 0.000 & 0.000 & 0.000 \\
\hline Months unemployed since left full-time education & -0.013 & 0.001 & 0.000 & -0.012 & 0.002 & 0.000 \\
\hline \multicolumn{7}{|l|}{ English proficiency (Australian-born omitted) } \\
\hline Good & -0.152 & 0.052 & 0.003 & -0.110 & 0.073 & 0.131 \\
\hline Poor & -0.478 & 0.180 & 0.008 & -0.558 & 0.315 & 0.077 \\
\hline \multicolumn{7}{|l|}{ Location (Sydney omitted) } \\
\hline Rest of New South Wales & -0.217 & 0.052 & 0.000 & -0.188 & 0.066 & 0.005 \\
\hline Melbourne & -0.101 & 0.046 & 0.029 & -0.167 & 0.057 & 0.003 \\
\hline
\end{tabular}




\begin{tabular}{|c|c|c|c|c|c|c|}
\hline Explanatory variables & Coef. & $\begin{array}{l}\text { Std. } \\
\text { error }\end{array}$ & Sig. & Coef. & $\begin{array}{l}\text { Std. } \\
\text { error }\end{array}$ & Sig. \\
\hline Rest of Victoria & -0.358 & 0.062 & 0.000 & -0.326 & 0.079 & 0.000 \\
\hline Brisbane & -0.235 & 0.054 & 0.000 & -0.142 & 0.068 & 0.037 \\
\hline Rest of Queensland & -0.277 & 0.053 & 0.000 & -0.237 & 0.068 & 0.001 \\
\hline Adelaide & -0.316 & 0.063 & 0.000 & -0.304 & 0.079 & 0.000 \\
\hline Rest of South Australia & -0.456 & 0.089 & 0.000 & -0.513 & 0.117 & 0.000 \\
\hline Perth & -0.060 & 0.060 & 0.316 & -0.236 & 0.080 & 0.003 \\
\hline Rest of Western Australia & -0.053 & 0.090 & 0.558 & -0.363 & 0.124 & 0.003 \\
\hline Tasmania & -0.419 & 0.098 & 0.000 & -0.310 & 0.107 & 0.004 \\
\hline Northern Territory & -0.241 & 0.151 & 0.110 & 0.266 & 0.189 & 0.158 \\
\hline Australian Capital Territory & -0.028 & 0.096 & 0.771 & -0.027 & 0.124 & 0.829 \\
\hline Number of dependent children aged 0-2 & -0.023 & 0.037 & 0.533 & -0.462 & 0.120 & 0.000 \\
\hline Number of dependent children aged 3-4 & 0.037 & 0.048 & 0.434 & -0.359 & 0.078 & 0.000 \\
\hline Number of dependent children aged 5-9 & -0.036 & 0.028 & 0.199 & -0.193 & 0.041 & 0.000 \\
\hline Number of dependent children aged 10-12 & -0.026 & 0.035 & 0.462 & -0.152 & 0.043 & 0.000 \\
\hline Number of dependent children aged 13-14 & 0.041 & 0.049 & 0.404 & -0.139 & 0.056 & 0.013 \\
\hline Has disability or long-term health condition & -0.430 & 0.097 & 0.000 & -0.299 & 0.117 & 0.011 \\
\hline Lambda & 0.494 & 0.217 & 0.023 & 0.333 & 0.324 & 0.304 \\
\hline Sample & \multicolumn{3}{|c|}{3,373} & \multicolumn{3}{|c|}{3,226} \\
\hline Adjusted R-sq & \multicolumn{3}{|c|}{0.303} & \multicolumn{3}{|c|}{0.203} \\
\hline $\mathrm{P}>\mathrm{F}$ & \multicolumn{3}{|c|}{0.000} & \multicolumn{3}{|c|}{0.000} \\
\hline
\end{tabular}

Source: Authors' calculations from the 2002 SIHC and HILDA Survey wave 3 
Table 4: RRs of unwaged DSP recipients ${ }^{\mathrm{a}}$, under existing DSP and NSA systems, 2002, percent

\begin{tabular}{|c|c|c|c|c|c|c|c|c|c|c|}
\hline \multirow{2}{*}{$\begin{array}{c}\text { Survey } \\
\text { Scenario }\end{array}$} & \multicolumn{5}{|c|}{ SIHC } & \multicolumn{5}{|c|}{ HILDA Survey } \\
\hline & $\begin{array}{c}\text { Outright } \\
\text { owner }\end{array}$ & $\begin{array}{l}\text { Owner } \\
\text { purchaser }\end{array}$ & $\begin{array}{c}\text { Private } \\
\text { renter }\end{array}$ & $\begin{array}{l}\text { Public } \\
\text { renter }\end{array}$ & Total & $\begin{array}{c}\text { Outright } \\
\text { owner }\end{array}$ & $\begin{array}{c}\text { Owner } \\
\text { purchaser }\end{array}$ & $\begin{array}{l}\text { Private } \\
\text { renter }\end{array}$ & $\begin{array}{l}\text { Public } \\
\text { renter }\end{array}$ & Total \\
\hline \multicolumn{11}{|l|}{ Mean RR } \\
\hline DSP & 63.5 & 65.5 & 60.3 & 68.5 & 63.9 & 62.5 & 62.7 & 65.6 & 69.4 & 64.8 \\
\hline NSA & 71.1 & 71.5 & 64.5 & 74.5 & 69.9 & 65.0 & 65.1 & 68.8 & 74.0 & 67.9 \\
\hline Percentage point difference & 7.6 & 6.1 & 4.2 & 6.0 & 6.1 & 2.5 & 2.4 & 3.3 & 4.6 & 3.1 \\
\hline \multicolumn{11}{|l|}{ Median $R R$} \\
\hline DSP & 62.1 & 64.7 & 59.6 & 70.2 & 62.9 & 61.0 & 61.1 & 64.6 & 67.0 & 64.1 \\
\hline NSA & 72.0 & 74.8 & 67.3 & 78.1 & 71.6 & 67.5 & 66.3 & 72.0 & 76.9 & 70.0 \\
\hline Percentage point difference & 9.9 & 10.0 & 7.7 & 7.9 & 8.7 & 6.5 & 5.3 & 7.4 & 9.9 & 5.9 \\
\hline \multicolumn{11}{|c|}{ Percent of cases with $R R>75 \%$} \\
\hline DSP & 8.9 & 25.1 & 7.9 & 20.5 & 13.2 & 14.9 & 17.7 & 22.5 & 30.6 & 20.7 \\
\hline NSA & 43.7 & 48.2 & 21.9 & 64.6 & 42.1 & 23.1 & 20.1 & 43.0 & 59.0 & 35.4 \\
\hline Percentage point difference & 34.7 & 23.1 & 14.0 & 44.1 & 28.9 & 8.2 & 2.5 & 20.5 & 28.4 & 14.7 \\
\hline \multicolumn{11}{|l|}{ Number of cases } \\
\hline Sample & 207 & 80 & 163 & 131 & 581 & 104 & 57 & 95 & 74 & 330 \\
\hline Population ('000s) & 164 & 63 & 129 & 87 & 442 & 151 & 69 & 102 & 90 & 412 \\
\hline
\end{tabular}

Source: Authors' calculations from the 2002 SIHC and HILDA Survey wave 3

Notes:

a. The sample excludes unwaged DSP recipients who own businesses or investment properties.

b. Estimates are weighted by population weights or expansion factors to produce estimates for the whole population. This procedure ensures that the survey estimates conform to benchmarks that are based on the numbers of persons and households in the Australian population. 
Welfare to Work in Australia: disability income support, housing affordability and employment incentives 